\title{
Wojciech Puppel
}

Uniwersytet im. Adama Mickiewicza w Poznaniu

\section{ROLA GIER KOMPUTEROWYCH WE WSPÓŁCZESNEJ PRZESTRZENI EDUKACYJNEJ}

\section{SUMMARY}

The role of computer games in present-day educational space

The present article entitled "The role of computer games in present-day educational space" presents a view that this space should be understood as realized in two dimensions: the physical dimension of the traditional school and in the virtual dimension, partly formalized in school conditions and partly realized outside the space of the school, that is, in the more comfortable conditions of the globalized cyberspace represented by the computer net. Such a radical enlargement of formal educational space is both inevitable and irrecoverable. In this way, the traditional Platonic system of education is further strengthened, despite some negative traits of such a tendency. The positive aspects of the dynamic changes accomplished in present-day educational space are duly emphasized.

Key words: computer network, computer games, cyberspace, virtual educational space, present-day educational space

\section{PEЗЮME}

\section{Роль комп'ютерних ігор в сучасному освітньому просторі}

Стаття «Роль комп'ютерних ігор в сучасному освітньому просторі» представляє погляд, згідно з яким ігровий простір сприймається як такий, що підлягає двом вимірам: виміру традиційної школи і виміру віртуальному. Віртуальний вимір як частина глобального 
кіберпростору набагато комфортніший. Наявність цього простору $\epsilon$ неминучою. Таким чином, традиційна Платонівська система освіти $\epsilon$ підкріплена багатьма позитивними особливостями віртуального простору.

\section{Uwagi wstępne}

Tradycyjny pogląd na edukację wyznacza jej miejsce w specjalnym przedziale społecznej globalnej przestrzeni ziemskiej, przestrzeni edukacyjnej, poświęconej szczególnej działalności związanej z międzypokoleniowym zdobywaniem, utrzymywaniem i rozwijaniem wiedzy. Przestrzeń edukacyjna w tradycyjnym rozumieniu tego terminu oznacza fizyczną przestrzeń zawierającą cały system szkół jako budynków rozmieszczony w globalnej przestrzeni ziemskiej wraz z budynkami mieszkalnymi zamieszkanymi przez nauczycieli i uczniów. W tak rozumianej przestrzeni, zapełnionej przedstawicielami populacji ludzkiej występującymi w społecznie pożądanych rolach 'nauczyciela' (tj. człowieka-wychowawcy i dawcy wiedzy) i 'ucznia' (tj. człowieka-wychowanka i biorcy wiedzy), interakcja 'nauczyciel-uczeń' odbywała się i odbywa się w obrębie specjalnych miejsc i budynków, określanych mianem 'szkoły', w określonym czasie dnia i na podstawie ustalonego z góry i usankcjonowanego przez instytucję szkoły sformalizowanego programu działania zwanego 'programem nauczania'. Program ten $w$ tradycji zachodniej, wypracowany przynajmniej już od czasów Solona i wyraźnie nakreślony przez Platona w jego Państwie i praktycznie sprawdzony w jego Akademii Platońskiej, sprowadzał realizację jego treści do fizycznych (a więc przestrzennie „stacjonarnych") granic szkoły, w której uczniów poddawano formalnemu instruktażowi obejmującemu stałe części składowe (komponenty). Należały do nich:

(a) ustny wykład treści nauczania (ustna ekspozycja materiału) przez nauczyciela,

(b) komponent pytań i odpowiedzi oraz

(c) towarzyszący tym dwom składnikom element nauki właściwego zachowania się ucznia w grupie społecznej (wychowanie).

Możemy więc w perspektywie historycznej mówić o ustanowieniu szkoły platońskiej jako powszechnie przyjętego modelu istnienia szkoły w warunkach cywilizacji osiadłej agrarno-miejskiej. Model platoński realizowany jest obecnie nadal w ogólnych zarysach w skali globalnej i obejmuje wszystko to, co Wincenty Okoń określił precyzyjnie w następujący sposób: „ogół szkół i przedszkoli wraz 
z nauczycielami, uczniami, programami, bazą lokalowo-terenową i innymi instytucjami społecznymi i kulturalnymi"1.

Wraz z pojawieniem się gier komputerowych jako nowego zjawiska w wymiarze kultury masowej, obejmującego swoim zasięgiem przede wszystkim najmłodszych członków populacji ludzkiej, w warunkach funkcjonowania tradycyjnej (tj. platońskiej) szkoły w rozumieniu zdefiniowanym powyżej, pojawiło się nowe zjawisko spędzania wolnego czasu (tj. czasu zabawy i konsumpcji poprzez zabawę) $)^{2}$, którego powszechność wprowadziła w sposób naturalny zupełnie nowy wymiar do edukacji masowej w warunkach coraz bardziej upowszechniającego się urbanistycznego modelu życia. Rosnący udział gier komputerowych w zagospodarowywaniu czasu wolnego u dzieci i młodzieży (ale także w starszych grupach wiekowych) pozwala już dzisiaj sformułować przekonanie, że gry komputerowe są nie tylko ważnym elementem kultury masowej nastawionej na utrwalanie postawy ludycznej ${ }^{3}$, którego doniosłość będzie rosła wraz z coraz to powszechniejszym dostępem do komputerów osobistych, ale że także stanowić one będą w bliższej i dalszej przyszłości istotny i nieodwracalny element przestrzeni edukacyjnej, $\mathrm{z}$ jednej strony rozumianej tradycyjnie po platońsku i realizowanej w zgodzie z tymże modelem nie tylko w cywilizacji zachodniej ale także w skali całego globu, zarówno w edukacji podstawowej jak i w kształceniu nieustannym/ustawicznym (ang. life-long education) ${ }^{4}, \mathrm{z}$ drugiej zaś strony poszerzy przestrzeń edukacyjną o nowy wymiar wirtualny ${ }^{5}$. To ostatnie zjawisko może w istotny sposób wpłynąć na wprowadzenie fundamentalnych, wręcz rewolucyjnych i nieodwracalnych zmian $\mathrm{w}$ tradycyjnym rozumieniu i organizacji istnienia szkoły jako głównej instytucji przestrzeni edukacyjnej w globalnym coraz bardziej urbanistycznym i wymagającym coraz bardziej zbiorowego współdziałania modelu życia społecznego ${ }^{6}$.

1 W. Okoń, Stownik pedagogiczny, Warszawa 1984 (2008).

2 J. Grad, Badania uczestnictwa w kulturze artystycznej w polskiej socjologii kultury, Poznań 1997.

3 J. Grad, Badania uczestnictwa..., op. cit.; W. Puppel, Uczestnictwo w kulturze masowej w epoce cyberkultury na przykładzie gier komputerowych, Kraków 2014.

4 I. Illich, Społeczeństwo bez szkoty, Warszawa 1976; W. Okoń, Stownik pedagogiczny..., op. cit.; J. Skrzypczak (red.), Popularna encyklopedia mass mediów, Poznań 1999.

5 J. Izdebska, Młodzież - media elektroniczne. Nowa przestrzeń edukacyjna, „Edukacja Medialna” 2003, s. 22-26.

6 W. Skrzydlewski, Dokąd zmierza technologia kształcenia, Poznań 1993; W. Skrzydlewski (red.), Kompetencje medialne społeczeństwa wiedzy, Poznań 2004. 


\section{Obecność technologii komputerowej w edukacji masowej początku XXI wieku}

Istotną cechą gier komputerowych jest ich strona technologiczna. Użycie gry komputerowej i korzystanie $\mathrm{z}$ niej realizowane są poprzez konieczne spełnienie przez gracza warunku dostępu do najnowszej technologii nośników elektronicznych, tj. dostępu do powszechnego już dzisiaj, skomplikowanego i zarazem niezwykle atrakcyjnego narzędzia, jakim jest komputer osobisty. Zatem to właśnie owa coraz bardziej rosnąca obecność komputera w życiu społecznym prawdziwie na skalę globalną stanowić będzie w najbliższych latach o nowym kształcie technologicznym współczesnej edukacji i nowym rozumieniu funkcjonowania współczesnej przestrzeni edukacyjnej w ramach tradycyjnego modelu platońskiego.

Rosnąca na naszych oczach statystyczna przewaga komputera osobistego nad innymi narzędziami zabawy oraz tradycyjnymi nośnikami wiedzy (np. takimi jak nośniki drukowane w postaci e-książek (ang. ebooks), a więc podręczników, encyklopedii, przewodników etc.), jego niezwykła atrakcyjność a także łatwość w nabyciu i użyciu powodują, że trudno sobie dzisiaj wyobrazić dziecko w wieku szkolnym, które nie słyszało o komputerze bądź osobiście nie doświadczyło, choćby na krótki czas, kontaktu z tym narzędziem, głównie zresztą poprzez gry komputerowe. Tak więc w niniejszym krótkim opracowaniu położony będzie szczególny nacisk na wszechobecność technologii komputerowej w wydaniu masowym (można powiedzieć, swoiście nawet 'kieszonkowym' jak chociażby w zminiaturyzowanej postaci telefonów komórkowych czy tzw. pocket PC bądź coraz popularniejszych tabletów), jako warunku podstawowym prowadzącym do masowego powstawania domowych centrów cyberrozrywki i cyberedukacji, i wyraźnie rosnącym wpływie tego zjawiska na funkcjonowanie dzisiejszej przestrzeni edukacyjnej, w sposób nieodwracalny poszerzonej o wymiar wirtualny ${ }^{7}$.

Tak zdecydowana obecność tego nowego i technicznie najbardziej zaawansowanego narzędzia, jakim jest komputer, w kontekście równie nowego i powszechnego zjawiska kultury masowej, jakim jest gra komputerowa adresowana głównie do najmłodszych członków populacji, każe postawić przynajmniej dwa podstawowe pytania:

(1) czy gry komputerowe mogą stanowić - być może nawet nieodzowny i nieodwracalny - element strukturalny dzisiejszej edukacji formalnej, uzupełniając w istotny sposób klasyczny model platoński we wszystkich jego wymiarach na nowej osi edukacyjnej ‘szkoła - sieć komputerowa jako

7 D. Urbańska-Galanciak, Homo players. Strategie odbioru gier komputerowych, Warszawa 2009. 
przestrzeń bez szkoły'? (zob. także np. Illich i jego dezaprobata dla szkoły jako instytucji ${ }^{8}$.

(2) Jeśli odpowiedź na pytanie pierwsze jest pozytywna, to dlaczego tak jest (a więc czym są lub czym mogą się stać gry komputerowe we współczesnej globalnej przestrzeni edukacyjnej, czyli jakie mogą być główne zalety i zagrożenia związane z grami komputerowymi)?

Odpowiedź na pierwsze pytanie nie wydaje się specjalnie trudna, bowiem przychodzą na myśl wszystkie poprzednie wielkie innowacje, które człowiek wraz z następującą po ich wprowadzeniu szeroką dystrybucją stopniowo i konsekwentnie wprowadzał do ówczesnej przestrzeni edukacyjnej. Tak stało się z papierem, książką, fotografią, radiem, filmem, taśmą audio i taśmą wideo. Tak samo stało się już w latach dziewięćdziesiątych ubiegłego wieku z komputerem osobistym i podobnie z pewnością przytrafi się to w najbliższej przyszłości grze komputerowej.

Już więc dziś gry komputerowe jawią się jako ważne elementy formalne, chociaż jeszcze $\mathrm{w}$ wymiarze jedynie uzupełniającym tradycyjne nauczanie, na przykład w instruktażu z zakresu nabywania znajomości oraz umiejętności komunikacyjnych w językach obcych'. Także czołowe osobistości z życia politycznego wypowiadają się za wprowadzeniem gier komputerowych do programów edukacyjnych. I tak na przykład w ostatnim czasie Prezydent USA, Barack Obama, opowiedział się za wprowadzeniem niektórych gier o charakterze komercyjnym (np. gry Little Big Planet) do szkół podstawowych celem skuteczniejszego przyciągnięcia dzieci do nauki przedmiotów ścisłych. Wtórują mu w tych planach gotowe do podjęcia natychmiastowego działania największe koncerny elektroniczne jak Sony, Microsoft, czy Entertainment Software Association.

Stanowisko takie jest wyrazem stopniowo rosnącego przekonania, że obecność gier w życiu dzieci i młodzieży nie prowadzi tylko i wyłącznie do kształcenia rzesz motorycznie sprawnych idiotów, lecz, że to gry właśnie, widziane w szerszym kontekście „scenografii” multimedialnej homo mediens, charakterystycznej dla

8 H. von Schoenebeck, Antypedagogika. Kongruencyjna radość życia, [w:] Teoretyczne podstawy edukacji alternatywnej, B. Śliwerski (red.), Kraków 2009, s. 189-196; H. M. Griese, Koniec pedagogiki? Socjologiczno-prowokacyjna perspektywa, [w:] Teoretyczne podstawy edukacji alternatywnej..., s. 321-330.

9 B. Szumilewicz, Miejsce i rola programów komputerowych w dydaktyce, Poznań 1990; P. Hubbard, Evaluating computer games for language learning, „Simulation and Gaming” 1991, No. 22.2., s. 220-223; J. P. Gee, Pleasure, learning, video games, and life: the projective stance, „E-Learning” 2005a, No. 2.3., s. 211-223; J. P. Gee, The classroom of popular culture: what video games can teach us about making students want to learn, „Harvard Education Letter” 2005b, November/December; A. Surdyk (red.), Kulturotwórcza funkcja gier, Poznań 2007; M. Filiciak, Zabawa naszych czasów, „Nowa Polszczyzna” 2005, nr 4, s. 7-11. 
kształtującego się nowego wymiaru człowieczeństwa ${ }^{10}$, podnoszą ogólny poziom inteligencji poszczególnych uczniów i odpowiednio zwiększają szanse najmłodszych na wzięcie skuteczniejszego udziału w postępie cywilizacyjnym ${ }^{11}$.

Zatem biorąc pod uwagę bardzo pozytywny los poprzednich innowacji w zakresie komunikacji masowej a także stopniowo rosnąca presję ze strony świata nauki, polityki i biznesu oraz przedstawicieli przemysłu obsługującego kulturę masową w jej wydaniu ludycznym i co równie ważne, wyraźnie ze strony głównych zainteresowanych, tj. dzieci i młodzieży, należy założyć bez specjalnego ryzyka, że gry komputerowe prędzej czy później (można założyć, że raczej prędzej) włączone zostaną ostatecznie do standardowych środków dydaktycznych w globalnej rzeczywistej przestrzeni edukacyjnej, powodując jej istotne rozszerzenie (lub raczej jej uzupełnienie) o rzeczywistość wirtualną, chociaż z pewnością sam proces przebiegał będzie nierównomiernie. Będzie się to raczej wiązało z czynnikiem ekonomicznym, a więc z istniejącym w świecie głębokim zróżnicowaniem w zakresie stopnia zamożności danego społeczeństwa i danego państwa decydującego się na wdrażanie takiego programu, a także ze stopniem akceptacji gier komputerowych jako istotnego uzupełnienia bardziej tradycyjnych technik nauczania i uczenia się ze strony samych nauczycieli.

Proces poszerzania globalnej rzeczywistej przestrzeni edukacyjnej do wirtualnej przestrzeni edukacyjnej można przedstawić graficznie w następujący sposób:

\section{Rzeczywista przestrzeń edukacyjna}

(ogół szkół i przedszkoli wraz z nauczycielami, uczniami, programami, bazą lokalowo-terenową i innymi instytucjami społecznymi i kulturalnymi tworzące tradycyjny formalny system edukacyjny)

\section{Wirtualna przestrzeń edukacyjna}

(poszczególne komputery osobiste połączone w systemy lokalnych sieci komputerowych, tworzące z kolei globalną sieć komputerową jako istotną część składową nowo powstającego formalnego systemu edukacyjnego obejmującego obydwie przestrzenie)

10 J. Kwitek, Homo mediens vs „człowiek uniwersalny”?, [w:] Media i społeczeństwo. Nowe strategie komunikacyjne, M. Sokołowski (red.), Toruń 2008, s. 40-55.

11 W. Strykowski (red.), Scenariusze zajęć z edukacji czytelniczej i medialnej, Poznań 2002; W. Strykowski, W. Skrzydlewski (red.), Media i edukacja w dobie integracji, Poznań 2002; W. Puppel, Rola efektu multimedialnego w dydaktyce, [w:] Transkomunikacja, S. Puppel (red.), Poznań 2011, s. 101-111. 
Natomiast odpowiedź na drugie pytanie wymaga głębszej analizy poznawczo-pedagogicznego wymiaru programów i gier komputerowych ${ }^{12}$, a więc bardziej szczegółowego ustalenia, co zyskają zarówno uczniowie (także studenci) i nauczyciele przy formalnym wprowadzeniu gier komputerowych do współczesnej przestrzeni edukacyjnej i w odniesieniu do powyżej wymienionych tradycyjnych elementów platońskiego procesu dydaktycznego. Stosowna w takim punkcie analiza cech negatywnych związanych $\mathrm{z}$ grami komputerowymi odnosi się w szczególności do następujących elementów:

- gry komputerowe, zwłaszcza obecne w życiu dzieci, mogą spowodować czysto fizyczne dolegliwości znane jako 'repetitive strain injury' (RSI), takie jak: ból oczu, nadgarstków, szyi, pleców, halucynacje, bóle głowy, uszkodzenia nerwów i mięśni, ukształtowanie się wadliwej postawy, etc. Jest to efektem długotrwałych nieergonomicznych warunków miejsca pracy,

- gry komputerowe mogą wpływać na bardziej jednostronny rozwój mózgu, co postulują badania nad aktywnością mózgową dzieci spędzających długie godziny przy komputerze, np. badania profesora Ruyty Kawashimy z Uniwersytetu w Tohoku (Japonia), który stwierdził, że u dzieci grających w Nintendo dochodzi do bardziej jednostronnych stymulacji głównie tych części mózgu, które są odpowiedzialne za wzrokowość i ruch, podczas gdy gry arytmetyczne wyraźnie jednocześnie stymulują obie półkule w płatach czołowych i zatem bardziej całościowo wpływają na ogólne funkcjonowanie pamięci, uczuć i ogólny przebieg procesów uczenia się,

- gry komputerowe mogą powodować wyraźne zakłócenia w przebiegu porządku czynności dnia codziennego,

- gry komputerowe mogą prowadzić do zakłóceń w wymiarze społecznym, jak np. rozwoju poczucia osamotnienia, rozwoju introwersji, aprobaty dla postawy agresywnej w życiu społecznym, powstawania zjawiska uzależnienia od komputera czy Internetu ${ }^{13}$,

- gry komputerowe mogą prowadzić do powstawania u młodocianych graczy zakłóceń w wymiarze psychologicznym, jak np. występowania stanów obsesyjnych, depresyjnych i lękowych, utrzymywania niskiej samooceny i niedowartościowania, także zjawiska „odwrażliwienia” (tj. od-

12 M. Sokołowski (red.), Media i społeczeństwo. Nowe strategie komunikacyjne, Toruń 2008.

13 M. Griffiths, Technological Addiction, „Clinical Psychology Forum” 1996, nr 15, s. 161-162; T. Feibel, Zabójca w dziecinnym pokoju. Przemoc i gry komuterowe, Warszawa 2006; M. Jędrzejko, Śmierć jako zabawa - człowiek $w$ świecie gier komuterowych i sieciowych (spojrzenie socjopedagogiczne), „Media i Społeczeństwo" 2011, nr 1, s. 165-179. 
czulenia) i zobojętnienia na obecność innych ludzi w realnej przestrzeni publicznej ${ }^{14}$.

Tymczasem dość wczesnemu i wszechstronnemu rozpoznaniu elementów negatywnych związanych $\mathrm{z}$ obecnością gier komputerowych w przestrzeni publicznej towarzyszy jednak nie mniej szerokie rozpoznanie cech pozytywnych związanych z zaistnieniem gier komputerowych w tejże przestrzeni. Mają one dla niniejszego opracowania istotną wartość, bowiem pozwalają na wyraźne uzupełnienie tradycyjnego (tj. platońskiego) modelu edukacji zarysowanego powyżej. Tak więc krótka charakterystyka cech pozytywnych określających nową rzeczywistość wirtualną w obrębie tradycyjnego platońskiego modelu edukacyjnego (pkt. (a) - (c) powyżej) zawiera się w następującym wstępnym jej opisie:

Pkt. (a): komponent: ustny wykład treści nauczania:

- gra komputerowa stanowi nowe narzędzie o charakterze multimedialnym (hipermedialnym), za pomocą którego przeprowadzać można wielokrotnie powtarzalną ekspozycję materiału nauczania $w$ wybranych fragmentach lub w całości, łącząc wykład ustny z atrakcyjną wielobarwną szatą graficzną (wizualną) i obowiązkiem aktywnego zachowania się uczniagracza (podkreśla się wartość programów komputerowych jako programów zwiększających atrakcyjność uczenia ${ }^{15}$ ),

- nowe narzędzie pozwala na wielokrotne odtwarzanie nauczanego materiału w warunkach domowych, a więc minimalizując lub całkowicie usuwając element frustracji związany z koniecznością zapamiętania treści wykładu przedstawianego jednokrotnie w klasie (bądź sali wykładowej) w obecności nauczyciela,

- gra komputerowa wprowadza większą stymulację intelektualną ucznia poprzez łączenie tekstu mówionego $\mathrm{z}$ ruchomym i barwnym obrazem i jego estetyką oraz wprowadza aktywną postawą samego ucznia-gracza zmuszonego wykonywać określone działania przewidziane w scenariuszu gry,

- poprzez grę komputerową wprowadzona zostaje bardziej zrelaksowana postawa zabawy (postawa bardziej ludyczna) do wykładu treści nauczania, co wydatnie zwiększa atrakcyjność procesu nauczania i uczenia się oraz zwiększa skuteczność zapamiętywania informacji przez ucznia,

14 J. Konikowski, Chory na Internet, „Enter” 1999, nr 2., s. 94-96; J. Moczydłowska, Uzależnienie od komputera i Internetu, „Problemy Opiekuńczo-Wychowawcze” 1999, nr 4; P. Dębek, Złapani w sieć, „Chip” 2000, nr 4, s. 48-54; M. Jędrzejko, Śmierć jako zabawa..., op. cit.; W. Puppel, Uczestnictwo w kulturze..., op. cit.

15 K. Wieczorkowski, Metody informatyczne w kształceniu na dystans, „Neodidagmata” 1997, t. 23, 1997, s. 129-156. 
- gra komputerowa wprowadza bardzo atrakcyjny kontekst dla nauczania i uczenia się, łącząc encyklopedyczne treści komputerowego wykładu w formie narracyjnej $\mathrm{z}$ ogólną sprawnością percepcyjno-motoryczną ucznia-gracza.

Pkt. (b): komponent: pytania i odpowiedzi:

- gra komputerowa zawiera w sobie ogromny potencjał poznawczy, co rozpoznali już wystarczająco wyraźnie znani badacze gier komputerowych ${ }^{16}$,

- gra komputerowa zdecydowanie uatrakcyjnia postawę badawczą ucznia wobec danego problemu, tworząc niejako prywatną sferę wolności uczniagracza (co podkreślał w stosunku do gry jako takiej już sam Caillois ${ }^{17}$ ),

- gra komputerowa wzmacnia nieodzowny w poznaniu element ciekawości ucznia i wzmacnia tym samym chęć do dalszego systematycznego poznawania danego zjawiska czy problemu samodzielnie,

- gra komputerowa stymuluje umiejętność rozwiązywania problemów, gdyż sama natura gry zmusza ucznia do samodzielnego i aktywnego poszukiwania różnych rozwiązań w kontekście całości gry oraz stymuluje umiejętność podejmowania decyzji,

- gra komputerowa zmniejsza stopień frustracji ucznia pozwalając mu na stopniowe przyswajanie sobie treści nauczania poprzez wielokrotne powtarzanie poszczególnych sekwencji gry (lub nawet całej gry) w bardziej wygodnych i mniej psychicznie obciążających warunkach pozaszkolnych $^{18}$,

- gra komputerowa wzmacnia umiejętność dokonywania wyboru różnych rozwiązań danego problemu włącznie z możliwością dokonywania własnych wirtualnych innowacji,

- gra komputerowa wprowadza model bardzo skutecznego uczenia się nastawionego na umiejętności stosowania procedur i ich ewentualnych bieżących modyfikacji, oraz logicznego myślenia w kontekście całości, jaką jest dana gra komputerowa,

- gra komputerowa rozwija w uczniach-graczach nastawienie na osiąganie wyników, a nie tylko na mechaniczne przyswajanie faktów często niepowiązanych w większe całości tematyczno-logiczne,

- gra komputerowa wprowadza bardzo wyraźnie uwypukloną wrażliwość na wszelkie konteksty, w których następuje uczenie się (poprzez rozwiązywanie konkretnych problemów w samej grze),

16 J. Newman, Playing with Videogames, London 2008.

17 R. Caillois, Gry i ludzie, Warszawa 1997.

18 I. Illich, Społeczeństwo..., op. cit. 
- gra komputerowa wzmaga stopień uspołecznienia poprzez wzmocnienie znaczenia istotnego komponentu interakcyjności, czyli umiejętności i konieczności kontaktowania się gracza z innymi osobami (a więc zarówno innymi uczniami-graczami, jak i nauczycielami) w nabywaniu wiedzy i rozwiązywaniu problemów ${ }^{19}$ i dzieleniu się zdobytą wiedzą; w ten sposób proces nabywania wiedzy staje się czynnością społeczną, zatem społecznie preferowaną,

- gra komputerowa jako czynność poznawcza wzbogaca słowotwórstwo, wzmacnia wyobraźnię przestrzenną, poprawia pamięć i zdolność kojarzenia oraz prowadzi ogólnie do wzrostu ilorazu inteligencji, na co zwracał już uwagę w swoich pracach znany psycholog amerykański, Ulric Neisser $^{20}$, poprzez rozwiązywanie przez uczniów-graczy rozmaitych zadań przestrzenno-ruchowych $z$ jednoczesnym analizowaniem strumieni obrazów.

Pkt. (c): komponent: nauka właściwego zachowania się ucznia w grupie społecznej:

- gra komputerowa wzmacnia podejście do przestrzeni edukacyjnej jako „sieci wirtualnej”, a więc jako nowej przestrzeni multimedialnej o charakterze globalnym w zakresie nabywania wiedzy ${ }^{21}$,

- gra komputerowa dostarcza uczniowi-graczowi pewnego rodzaju bazy dla rozwoju społecznie pożądanej umiejętności współpracy z innymi osobami w nabywaniu wiedzy, w szczególności w formie udziału w grach zespołowych on-line,

- gra komputerowa wzmacnia w uczniach umiejętność dostosowywania się do występowania różnych i zmiennych kontekstów społecznych, zarówno w wymiarze rzeczywistym, jak i wirtualnym,

- gra komputerowa wzmacnia w uczniach konieczność osobistego zaangażowania się w czynności o charakterze poznawczym w coraz bardziej społecznym kontekście,

- gra komputerowa pozwala uczniowi-graczowi na wzięcie udziału w procesie zarządzania zasobami wiedzy i kształtuje w nim poczucie odpowiedzialności za całokształt przedsięwziętych przez siebie działań w zakresie przyswajania wiedzy,

19 J. F. Jensen, Interactivity: cracking a new concept in media and communication studies, [w:] Computer, media and communication: a reader, P. A. Mayer (red.), Oxford 1998, s. 160-187.

20 U. Neisser (red.), The rising curve:long term gains in IQ and related measures, „American Psychological Association” 1998; zob. też A. Mikołejko, O pożytkach z gier komuterowych, „Edukacja i Dialog” 2002, nr 3 (136), s. 67-70.

21 B. O. Szuprowicz, Multimedia networking, New York 1995. 
- gra komputerowa wzmacnia w uczniach-graczach postawę samokształceniową, gdyż pragnieniu zdobywania coraz to nowych gier towarzyszy pragnienie zdobywania nowej wiedzy zawartej w każdej nowej grze i nieodzownej do przeprowadzenia gry,

- gra komputerowa z konieczności wprowadza ucznia do swoistego wirtualnego 'teatru edukacyjnego' nastawionego na uczestnictwo w grach jako swoistych przedstawieniach ${ }^{22}$,

- gra komputerowa staje się w ten sposób wyraźnym sprzymierzeńcem edukacji wirtualnej (elektronicznej, ang. e-learning) w wydaniu masowym na wszystkich poziomach edukacji sformalizowanej, jak i w wymiarze kształcenia ustawicznego.

\section{Podsumowanie dyskusji - wstępne wnioski}

Zaproponowany powyżej opis rosnącego udziału gier komputerowych w kulturze masowej oraz we współczesnej przestrzeni edukacyjnej pozwala na wyciągnięcie następujących wstępnych wniosków:

a) powszechna komputeryzacja i dygitalizacja ( $\mathrm{tj}$. ucyfrowienie) przestrzeni społecznej praktycznie już intensywnie prowadzona w skali całego globu, w szczególności zaś globalne upowszechnienie dostępu dzieci i młodzieży do komercyjnych gier komputerowych jako nowego jakościowo i ilościowo zjawiska kultury masowej, każą rozumieć współczesną przestrzeń edukacyjną jako realizującą się w dwóch wymiarach: w rzeczywistej przestrzeni edukacyjnej i w obrębie tradycyjnej instytucji szkoły jak i w wirtualnej przestrzeni edukacyjnej, częściowo w formalnych warunkach szkoły, częściowo zaś w psychicznie mniej ucznia obciążających warunkach domu rodzinnego lub innego bardziej od szkoły komfortowego fragmentu przestrzeni pozaszkolnej, wyznaczonej zarówno przez lokalne sieci komputerowe, jak i globalną sieć komputerową,

b) postępujące nieustannie poszerzanie przestrzeni edukacyjnej o wymiar wirtualny (tj. cyberprzestrzeń) ma z pewnością charakter nieodwracalny i pozwala na stwierdzenie, że prowadzi ona do wyraźnego wzbogacenia tradycyjnego procesu dydaktycznego, odpowiednio wzmacniając różne jego elementy formalne, co zawiera zaproponowany powyżej opis, jak i uatrakcyjniając sam proces dydaktyczny,

22 G. Jones, Learning environments for collaborative authored outcomes: theatres for learning - a brief introduction, „The London Multimedia Laboratory for Audiovisual Composition and Communication. Research Report” LML-LUDIC-RR-002d 2005. 
c) tym samym wzbogacanie elementów tradycyjnego platońskiego modelu kształcenia, tj. całego kompleksu wykładu, pytań-odpowiedzi i wychowania, zdaje się być równomiernie rozłożone. Pozwala to na wystawienie ogólnie pozytywnej oceny zjawisku poszerzania rzeczywistej przestrzeni edukacyjnej o rzeczywistość wirtualną niezależnie od ewentualnych negatywnych cech, jakie niosą z sobą gry komputerowe. Niemniej elementy pozytywne zdają się przeważać w tak zarysowanym obrazie, co powinno usposabiać edukację współczesną zdecydowanie pozytywnie wobec obecności zjawiska gier komputerowych jako nowego hipermedium edukacyjnego.

\section{Bibliografia}

Caillois R., Gry i ludzie, Warszawa 1997. (Jest to polskie tłumaczenie pracy z 1958 roku: Man, Play and Games, Chicago: The University of Chicago Press).

Dębek P., Złapani w sié́, „Chip” 2000, nr 4, s. 48-54.

Feibel T., Zabójca w dziecinnym pokoju. Przemoc i gry komputerowe, Warszawa 2006.

Filiciak M., Zabawa naszych czasów, „Nowa Polszczyzna” 2005, nr 4, s. 7-11.

Gee J. P., Pleasure, learning, video games, and life:the projective stance, „E-Learning” 2005a, No. 2.3, s. 211-223.

Gee J. P., The classroom of popular culture: what video games can teach us about making students want to learn, „Harvard Education Letter” 2005b, November/December.

Grad J., Badania uczestnictwa w kulturze artystycznej w polskiej socjologii kultury, Poznań 1997.

Griese H. M., Koniec pedagogiki? Socjologiczno-prowokacyjna perspektywa. [w:] Teoretyczne podstawy edukacji alternatywnej, Śliwerski B. (red.), Kraków 2009, s. 321-330.

Griffiths M., Technological addiction, „Clinical Psychology Forum” 1996, No. 15, s. 161-162.

Hubbard P., Evaluating computer games for language learning, „Simulation and Gaming” 1991, No. 22.2, s. 220-223.

Illich I., Społeczeństwo bez szkoły, Warszawa 1976.

Izdebska J., Młodzież - media elektroniczne. Nowa przestrzeń edukacyjna. „Edukacja Medialna” 2003, nr 1, s. 22-26.

Jensen J. F., Interactivity:tracking a new concept in media and communication studies, [w:] Computer, media and communication: a reader, P. A. Mayer (red.), Oxford 1998, s. 160-187.

Jędrzejko M., Śmierć jako zabawa - człowiek w świecie gier komputerowych i sieciowych (spojrzenie socjopedagogiczne), „Media i Społeczeństwo” 2011, nr 1, s. 165-179.

Jones G., Learning environments for collaborative authored outcomes: theatres for learning - a brief introduction, „The London Multimedia Laboratory for Audiovisual Composition and Communication. Research Report" LML-LUDIC-RR-002d 2005.

Konikowski J., Chory na Internet, Enter 1999, nr 2, s. 94-96.

Kwiek J., Homo mediens vs 'człowiek uniwersalny'?, [w:] Media i społeczeństwo. Nowe strategie komunikacyjne, M. Sokołowski (red.), Toruń 2008, s. 40-55. 
Mikołejko A., O pożytkach z gier komputerowych, „Edukacja i Dialog” 2002, nr 3 (136), s. 67-70.

Moczydłowska J., Uzależnienie od komputera i Internetu, „Problemy Opiekuńczo-Wychowawcze” 1999, $\mathrm{nr} 4 / \mathrm{V}-\mathrm{VI}$.

Neisser U. (red.), The rising curve:long-term gains in IQ and related measures, „American Psychological Association" 1998.

Newman J., Playing with videogames, London 2008.

Okoń W., Słownik pedagogiczny, Warszawa 1984. (Nowe uzupełnione wydanie, Nowy słownik pedagogiczny, Warszawa 2008).

Puppel W., Rola efektu multimedialnego w dydaktyce, [w:] Transkomunikacja. W stronę sprofilowania przestrzeni publicznej jako wielopłaszczyznowej przestrzeni komunikacyjnej, S. Puppel (red.), Poznań 2011, s. 101-111.

Puppel W., Uczestnictwo w kulturze masowej w epoce cyberkultury na przykładzie gier komputerowych. Nieopublikowana rozprawa doktorska. Uniwersytet Jagielloński, Kraków 2014.

Skrzydlewski W. (red.), Kompetencje medialne społeczeństwa wiedzy, Poznań 2004.

Skrzydlewski W., Dokąd zmierza technologia kształcenia, Poznań 1993.

Skrzypczak J. (red.), Popularna encyklopedia mass mediów, Poznań 1999.

Strykowski W. (red.), Scenariusze zajęć z edukacji czytelniczej i medialnej, Poznań 2002.

Strykowski W., Skrzydlewski W. (red.), Media i edukacja w dobie integracji, Poznań 2002.

Surdyk A. (red.), Kulturotwórcza funkcja gier, Poznań 2007.

Szumilewicz B., Miejsce i rola programów komputerowych w dydaktyce (na przykładzie języka angielskiego jako obcego). Nieopublikowana rozprawa doktorska. Uniwersytet im. Adama Mickiewicza (Wydział Neofilologii) Poznań 1990.

Szuprowicz B. O., Multimedia networking, New York 1995.

Urbańska-Galanciak D., Homo players. Strategie odbioru gier komputerowych, Warszawa 2009.

von Schoenebeck H., Antypedagogika. Kongruencyjna radość życia, [w:] Teoretyczne podstawy edukacji alternatywnej, B. Śliwerski (red.), Kraków 2009, s. 189-196.

Wieczorkowski K., Metody informatyczne w kształceniu na dystans, „Neodidagmata” 1997, t. 23, s. 129-156. 